\title{
Structuration and branding of a religious tourism product: catalonia sacra
}

\author{
Dolors Vidal Casellas* \\ Sílvia Aulet Serrallonga** \\ Neus Crous Costa*****
}

University of Girona, Spain

\begin{abstract}
This article aims to provide an overview of the products Catalonia has to offer in terms of religious tourism. The growing interest in this kind of tourism worldwide, and in Catalonia itself, along with the region's wealth of religious heritage (particularly connected to the Christian Church) contrast with the lack of religion-based tourism products available, which results in its absence from the region's image as a tourism destination. In view of this, the Faculty of Tourism (University of Girona), the Vic Bishopric's Albergueria-Centre for Cultural Dissemination and the Tarraconense Episcopal Conference's Interdiocese Secretariat for the Custody and Promotion of Holy Art (SICPAS) decided to address the situation with the help of funding from the Autonomous Government of Catalonia.

In order to re-position Christian religious heritage in the image of Catalonia as a tourist destination, the aforementioned parties embarked upon a project to set up a series of routes throughout the region, branded under the name Catalonia Sacra.
\end{abstract}

Keywords: religious tourism, routes, religious heritage, holy art, religious tourism product branding, symbolic meaning

\section{Introduction}

From the second half of the 20th century onwards, Catalonia's image as a tourist destination has been closely linked to the sun and sand product, while other parts of Spain have developed and consolidated other types of tourism product, from cultural shows (flamenco in Andalusia) to material cultural heritage (Burgos and Leon cathedrals).

It was not until the nineties that the Catalan tourism agency Turisme de Catalunya (current name Agència Catalana de Turisme), which is linked to the Autonomous Government of Catalonia, initiated a clear branding strategy for Catalonia as a tourist destination on the basis of five different product segments. These segments were, and still are, based on the following thematic areas: culture, gastronomy or cuisine, active-nature, golf, and wellness. Although organisations apply for membership themselves (only those public or private organisations who apply and pay a fee can be members, meaning they represent the tourism image of Catalonia for each of these areas), the initiative did represent a first step towards redirecting Catalonia as a tourist destination at a time when the sun and sand model was entering a crisis and other modes of tourism, such as cultural tourism, were becoming known.

Over recent years we have seen how the Agència Catalana de Turisme, the Department for Innova-

* Tourism Faculty, University of Girona, Spain. E-mail: dolors.vidal@udg.edu

** Tourism Faculty, University of Girona, Spain. E-mail: silvia.aulet@udg.edu

*** Tourism Faculty, University of Girona, Spain. E-mail: u1055773@correu.udg.edu 
tion, Universities and Enterprise (which was responsible for the Department of Tourism until the November 2010 elections) and public and private tourism agents have promoted different thematic routes throughout the region of Catalonia under the name of brands that are clearly intended to help define the cultural image of Catalonia not only in the minds of visitors but also residents. Thus, for example, we now find products such as Les Rutes del Pirineu Comtal (Routes through the Pyrenees), La Ruta del Modernisme (the Modernist Route) in Barcelona and El Triangle Dalinià (the Dali Triangle), to mention but a few.

As we can see, these brands of regional products reveal different facets of Catalan identity, in line with what marketing theory suggests should be transmitted by a a brand (and, by extension, the product or region behind it): "branding involves promoting the unique benefits that the tourist will experience while visiting the city [or region], rather than the city itself. Branding answers the question 'Why should I visit your city [region]?" (Kolb 2006: 18). Therefore, as already mentioned, brands help us to retain our tourist experience of a destination by means of epithets referring to the different attributes which combine together to comprise it.

Over the past 15 years, then, both local government and private organisations have worked to develop products and brands that satisfy the specific demand and value the region's existing resources, rather than trying to create new ones. Despite this effort, a growing segment is currently detected that demands products linked to religious or spiritual tourism. And this segment is being ignored. It is true that related products have been created and brands promoted, such as La Ruta del Císter, El Camí de Sant Jaume (English: St. James' Way) (since 2010) and even El Cami dels Bonshomes. In all of these cases, however, deficiencies are detected in the discourse when it comes to everything referring to sacred, spiritual or religious elements and there is a lack of know-how regarding how to meet existing demand. All this despite a broad and rich religious heritage already being constructed and in existence (Christian and other beliefs).

In this context the need arose to create a brand linked to a high-quality product that identified Catalonia with its religious Christian and holy past, emphasising the importance it has had for the region throughout its history. It is for this reason that 2008 witnessed the founding of "Catalonia Sacra" (a name that became the brand for the resulting product), a project undertaken by Tarraconense Episcopal Conference's Interdiocese Secretariat for the
Custody and Promotion of Holy Art (SICPAS), in coordination with the Faculty of Tourism and the University of Girona and the Vic Bishopric's Albergueria-Centre for Cultural Dissemination, with funding from the Autonomous Government of Catalonia. The aim of this article is to provide a brief description of the current situation regarding tourism in Catalonia, particularly in reference to cultural-religious tourism, followed by a presentation of the tourist brand and product Catalonia Sacra in its regional context.

\section{Catalonia in its current tourism context}

In recent decades tourism has become one of the main economic industries (whilst also having a strong social impact) in many parts of the world. As a specific branch of this phenomenon, cultural tourism appeared (or more accurately, was recognised) in the mid-nineties. In 1992, in its period forecasts for worldwide tourism up until the year 2000, the World Tourism Organization (UNWTO), although not directly mentioning cultural tourism, emphasised that changes in demand (due to more in-depth knowledge of destinations and more experience in travel) would lead on the one hand to a larger number of destinations and on the other to a greater segmentation of the products on the market. Adventure tourism and short breaks were given as examples relating to special interest tourism (within which we also find cultural and religious tourism, among others). It is also worth highlighting the work done by Greg Richards here, considered one of the fathers of research in this specific market segment and founder of the Association for Tourism and Leisure Education (ATLAS) special interest group "Research into Cultural Tourism", one of the profession's most renowned.

Throughout the nineties and up until the present day we have indeed witnessed a rise in the importance of travel and holidays aimed at cultural purposes among a growing number of tourists (whether as the main reason for travel or as an additional element), despite the inherent difficulties in the definition of cultural tourism (due to the broad meaning awarded the term "culture" and also the term "tourism") and, therefore, its systematic quantification.

Despite this lack of comparable quantitative data, various signs may be interpreted as a reflection of this increase. For example, in the case of Catalonia, we have seen a large increase in university institutions offering tourism studies and also, very recently, Master's and postgraduate programmes in cultural tourism (1 official 
Master's degree at the University of Girona and four private postgraduate and specialised programmes at the University of Barcelona and the CETT. With regard to religious tourism, this very academic year the University of Barcelona has begun to offer a (non-official) postgraduate programme on this subject; it is also worth highlighting the annual conference on religious tourism held at Montserrat Monastery since 2010.

Along with this, it is also worth bearing in mind that Spain as a whole occupies a very high position in terms of worldwide tourism image, within the top three when it comes to tourist destinations. In a national context, Catalonia is the main tourist destination for foreigners according to data produced by the National Statistics Institute (INE). Statistics on incoming travellers indicate that in 2009 a total of 52,231,098 people entered the country, $12,769,129(24.25 \%)$ of whom went to Catalonia. After Catalonia we find the Ballearic Islands (17.30\%), the Canary Islands (15.71\%) and Andalusia (14.10\%). With regard to domestic tourism $(171,903,646$ tourists), Catalonia is second in the ranking of preferred autonomous region destinations, with a total of 23,047,719 visitors, just behind the autonomous region of Andalusia (which received $29,285,636$ visitors).

\subsection{Tourism image}

According to data from Euromonitor International's Top City Destinations Ranking, Barcelona is fourth in the ranking of European cities in terms of arrival of millions of tourists, behind London, Paris and Rome, and 5 positions above Madrid. Since the Olympic Games were held in the city in 1992, it has become internationally positioned through different projects and events (the rebuilding of urban areas such as Montjuïc and El Raval, Gaudi Year in 2002, etc.), turning it into a veritable icon and worldwide tourist brand for Catalonia and on a national level.

This very positive global image of the region's capital is having repercussions, not only in terms of tourism, but also throughout Catalonia, improving its image and positioning, without forgetting the significance of other factors such as: its positioning as a sun and sand destination in the worldwide image (Costa Brava), the growing interest in Catalan cuisine (Ferran Adrià and other chefs awarded Michelin stars), and not to mention sports (Barcelona F.C., the World Motorcycle Championships).

Such is the positioning being achieved by Barcelona and Catalonia in terms of worldwide tourism image and the value awarded to religious heritage by society that the national body for promoting tourism, Turespaña, is currently evaluating the possibility of using the Sagrada Familia temple in Barcelona as a tourism icon for Spain (the primary image retained by visitors), like the Eiffel Tower in France or Big Ben in Britain. More specifically, results from the study on the Tourism Image of Catalonia presented by the Tourism Consortium of Catalonia in 2008 indicate that, although other products such as sun and sand still have a very important specific weight, also in terms of the positioning of its image, other modes like cultural tourism and city tourism are now establishing themselves and opening their own markets.

Currently, the item most valued by tourists is culture (8.3 points), and consequently the image perceived by tourists visiting Catalonia is mainly one of culture (41\%), but also as a nature destination (24\%). Among the tourism products that define Catalonia, sun and sand still plays a predominant role $(27 \%)$, although there is notable diversity, as a total of 12 different possibilities were mentioned in the study. The second block of responses comprises cultural tourism (15\%), city tourism (14\%) and nature tourism (13\%), products typical of a type of tourism which is more aware of the dynamics of the region being visited and, in theory at least, less aggressive. The remaining $31 \%$ is very diversified, but we can highlight some responses such as snow sports (8\%), rural tourism $(5 \%)$, and mountain $(5 \%)$ or sports tourism $(2 \%)$.

With regard to potential tourists (people who travel but have not yet visited the region), what is valued most highly about Catalonia, whether by Europeans or respondents from other parts of Spain, is first nature (44\% and 37\%, respectively), followed by culture (35\% and $27 \%)$ and "sensations" (9\% and 16\%).

In the case of potential tourists from other parts of Spain, the tourism products that define Catalonia are very diversified, and the 12 possible options are all found within the range of responses from $10 \%$ to $6 \%$. However, the higher percentages are for cultural tourism (10\%), sun and sand (9\%), city tourism (9\%), family tourism $(9 \%)$, nature tourism $(9 \%)$ and snow tourism (9\%). With regard to potential European tourists, the sun and sand product is most mentioned (18\%), followed by cultural tourism (15\%), nature tourism (11\%) and city tourism (10\%). In this case, family tourism (9\%) and snow (2\%) are less important. When considering the data presented in this study, we must consider religious tourism to be included within the category of cultural tourism. 


\subsection{The concept of religious tourism}

As happens with the concepts "tourism" and "cultural tourism", defining the concept of "religious tourism" is a complex task, as it includes a very broad range of aspects, motivations, behaviours, use and perception of holy space (Hakobyan, 2010). Thus, many different authors have attempted to define it, and it forms part of multidisciplinary studies.

We must bear in mind at least the following four important aspects when characterising religious tourism (Olsen and Timothy, 2006; Shinde, 2010):

a. The tourist-pilgrim dichotomy

b. Characteristics of trips made specifically for religious purposes

c. Economic aspects

d. The negative impacts of tourism on religious places and ceremonies

For the purposes of this article we are going to use the definition of religious tourism proposed in the book $l$ Pellegrino e il turista (Costa, $200 \mathrm{X}$, pp. 69-82): "religious tourism is the synthesis of traditional trips to a shrine and cultural trips designed, guided and regulated by religious organisations or for religious purposes", to which we might add that religious tourism uses the tourism sector structure as a basis, but is comprised of elements pertaining to religious experience that "transform its quality, purpose, pace and style of action" (Parellada, 2009).

As objectives of this branch of cultural tourism we may highlight a desire to connect with spiritual, religious, historical-cultural and artistic values, which implies a curiosity to find out about and perceive cultural and religious wealth, acquire values and relate historical-cultural events with religious phenomena. That said, taking an interest in cultural heritage excludes the undertaking of religious practices in the place being visited (Hakobyan, 2010).

Sacred places have diverse functions, depending on the visitor. For those faithful to a parti- cular religion, they may be places which carry a message or a system of values, a place for coming into contact with the mysterious and an artefact of interest. For a tourist they may represent a point of interest due to the works of art they contain, their architecture, location, atmosphere, or simply form part of a longer route.

\subsection{Religious tourism in Catalonia}

Catalonia is home to a significant number of shrines and places of worship linked to Christianity. In some cases they are small chapels that may or may not have hostels attached to them, shrines with a local tradition of pilgrimage on a given date, village churches, cathedrals, monasteries and abbeys preserved in a good or not so good condition, as well as others which have achieved world renown such as Montserrat Monastery.

As we have said, Christian religious heritage is of fundamental importance for the identity and cultural roots of Catalonia and in recent years the first specific tourism products associated with holy and Catholic heritage have appeared, despite the fact that this type of heritage has not established itself globally; quite the contrary, in fact, as it has been losing relative importance within the context of global tourism products whilst other products and brands have become more established.

Proof of its relevance to both Catalan society and professionals in the tourism sector is Turespaña's plan to use the Sagrada Família temple as an icon for promoting Spain, although we could also cite other proof such as the Catàleg d'Icones de Catalunya (the Autonomous Government of Catalonia's Catalogue of Icons in Catalonia) and intangible resources (Atles del Turisme de Catalonia, English: Atlas of Tourism in Catalonia), which include a high percentage of religious heritage resources in general and Christian in particular.

Table 1: Intangible religious resources in Catalonia. Source: Atles del Turisme a Catalonia

\begin{tabular}{|l|l|}
\hline \multicolumn{2}{|c|}{ Intangible religious resources in Catalonia } \\
\hline Name of resource (total: 40) & \multicolumn{1}{c|}{ Geographical location } \\
\hline Muslims and Moors & Tortosa, Lleida, Ascó, Balaguer La Suda \\
\hline Witch-hunting & $\begin{array}{l}\text { Guilleries, Cervera, Sant Feliu Sasserra Sant Feliu Sasserra, hold an annual } \\
\text { fair and will have a centre of interpretation with local government support }\end{array}$ \\
\hline Medieval splendour & $\begin{array}{l}\text { Montblanc, Vallbona, Poblet, Santes Creus, Barcelona, Salou La Ruta del } \\
\text { Císter, via Montblanc, Vallbona, Poblet (mausoleum of counts and kings). } \\
\text { Santa Maria del Mar, in Barcelona. Intercultural Dialogue l (Drassanes...) }\end{array}$ \\
\hline Jews & Girona, Besalú, Barcelona, Berga Plaça Sant Pere de Berga (Jewish street) \\
\hline
\end{tabular}


Table 2: 116 religious icons in Catalonia. Source: Autonomous Government of Catalonia

\begin{tabular}{|c|c|}
\hline \multicolumn{2}{|r|}{116 tourism icons in Catalonia } \\
\hline Number & Name \\
\hline 2 & The facáde of Ripoll Monastery \\
\hline 21 & $\begin{array}{l}\text { The procession and dance of the dead } \\
\text { in Verges }\end{array}$ \\
\hline 22 & Saint George's Day \\
\hline 23 & La Moreneta \\
\hline 24 & La festa de la Patum \\
\hline 25 & Saint John's Day Bonfires \\
\hline 39 & $\begin{array}{l}\text { El Pantocràtor de Sant Climent de } \\
\text { Taüll }\end{array}$ \\
\hline 40 & The altar front in Avià \\
\hline 47 & L'Esculapi d'Empúries \\
\hline 48 & $\begin{array}{l}\text { El davallament d'Erill la Vall i La } \\
\text { Majestat Batlló }\end{array}$ \\
\hline 49 & Sant Carlemany \\
\hline 52 & Visigoth-Romanesque churches \\
\hline 53 & Sant Pere de Rodes Monastery \\
\hline 55 & Santa Maria del Mar Church \\
\hline 56 & La Seu Vella in Lleida \\
\hline 61 & La Sagrada Familia and La Pedrera \\
\hline 77 & Els pastorets \\
\hline 105 & Montserrat \\
\hline
\end{tabular}

As we can see from the above tables, L'Atles del Turisme basically ackowledges as an intangible resource those values related to spiritual faiths other than the Christian (Jewish, Moors and pagan cults), but does not include the former, which may be considered the main one and that to have contributed to forming the region's identity.

As for the list of 116 tourism icons in Catalonia, although $45 \%$ of its elements are religious (42.5\% Christian), it does not have a section specifically dedicated to holy icons, faith or religion and considers Montserrat, for example, to be a geological icon (its interest in this respect is undeniable, but so is its religious aspect). In summary then, all of the above leads us to state that, despite the demand this type of product awakens and the high potential of the Catalan region to offer interesting and high-quality products, there is a lack of identification of existing resources to link them specifically with religion, and also the creation and positioning of brands (and products). Perhaps the only exception we might cite is the Catalan branch of the St. James' Way (El Camí de Sant Jaume), which has a clearly positioned international image as a religious and active tourism product (it is important to acknowledge, however, that merit for its promotion has until now been due to the authorities of other autonomous regions, particularly Galicia).

\section{Catalonia Sacra}

On the basis of the above, Christian religious heritage, which is of fundamental importance from the perspective of identity and the cultural roots of our country, has lost relative weight in the context of the sum of tourism products on offer: many new products have appeared that structure or present the tourism products and heritage on offer in Catalonia very differently and diversely, such as Port Aventura, water parks, the Network of Spanish Jewish Quarters, industrial heritage, etc., not to mention the numerous products linked to natural heritage; whereas heritage linked to Christianity has not established itself as a widely-recognised product.

Although some of the products on offer may be related to religious heritage, we will not consider this an exclusive central theme, particularly in terms of discourse. None of these products were the fruit of an initiative on the part of the Church, an institution that was once a promotor and is now a depository, manager and main user of this huge set of heritage assets. There is also the case of monuments which, originally linked to the Church, are today owned by public administrations, now in charge of their preservation and promotion; the Church, on the other hand, is responsible for providing similar services for monuments that depend upon it. By assuming this responsibility, the Church in Catalonia and the country itself become particularly aware of their inseparable union in history and identity. Assessment of all of the factors involved here (existence and distribution of heritage assets, individual use of these assets for tourism purposes, flows of visitors, qualitative analyses) leads to a series of realisations that depict a panorama of enourmous opportunity for organising and coordinating the heritage of the Catalan Church into structured routes.

\subsection{Description of the project}

The purpose of Catalonia Sacra is to make available to visitors - whether or not they are Catalan - organised routes visiting the leading sites in the Christian geography of Catalonia. 
This should allow them to gain knowledge and experience of history, culture, art and spirituality, also in their specifically Catalan aspects, explained and managed by the Church itself.

It is therefore a question of offering guidelines for reading these assets linking them to their origins and primordial uses, with their own meaning and with the existence of all these factors in a specific setting - the Catalan dioceses. But offering reading guidelines not only involves providing the visitor with what might appear to be an "alternative key", it also means integrating all the information into a coherent whole that facilitates intellectual interpretation and personal experience and shows up the rich layers of this venerable heritage.

In general terms, this means including specific factors from this religious heritage in the discourse which are, perhaps, not normally taken into account systematically. The heritage linked to the Church constitutes a large percentage of the evidence for the tangibility, establishment and characteristics of religion in Catalonia during the most essential part of its history. Without any wish to downplay the other religions historically present on Catalan territory, this means Christianity as it manifested itself and developed in Catalonia. In addition then, for the public interested in religious and spiritual tourism, Catalan religious heritage, particularly the elements still used today for religious purposes by parish, cathedral, monastic or convent communities, is the

\section{Map 1: The 10 bishoprics comprising the Tarraconense Episcopal Conference. Source: Tarraconense Episcopal Conference}

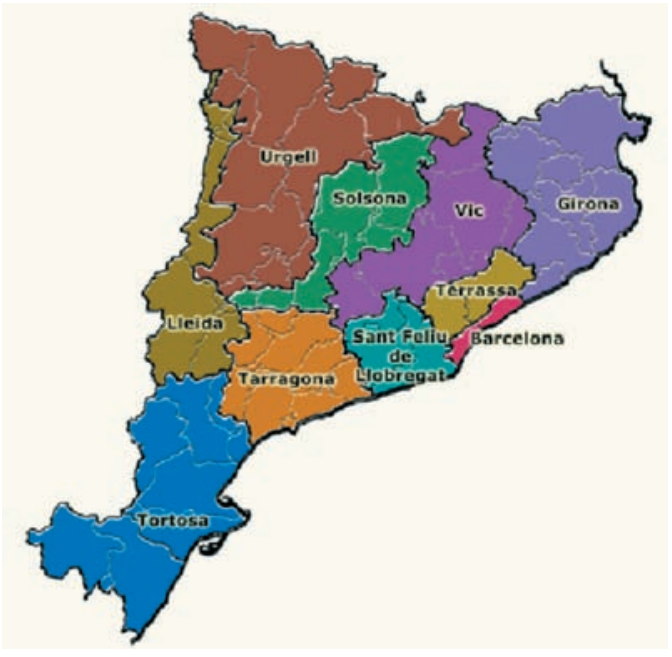

means by which to better and more directly communicate what can be understood as the character and singular features of Catalan spirituality.

In this sense, the specific visibility of the Church in Catalonia affects the visibility of Catalonia in general within the Spanish State and beyond, as it provides the image of an integrated heritage which will have to be taken into consideration in the State as a whole. From this territorial perspective, it must be borne in mind that at certain points the project must go beyond the limits of the Catalan territory, based on the decision to cover the entire area of the dioceses of Urgell (which includes the Principality of Andorra) and Tortosa (which includes part of the province of Castelló de la Plana, in the Valencian region).

\subsection{The brand name}

The brand constitutes a mental representation of the perceived attributes and benefits of a product or service. It can be defined as a set of ideas, beliefs and impressions people have of a particular entity. Visitors' behaviour when it comes to choosing a tourist product largely depends on their image of it and its inherent quality, as the tourist experience, by nature, is broadly based on preconceived images. Tourists therefore buy the mental images created of a destination (which need to correspond to reality) rather than the actual places (these concepts have been developed at length by authors like Urry, 1990).

The question of perceived-authenticity depends on the expectations for potential visitors, which inevitably leads to dissatisfaction and possible failure; it must be focused on 1 or 2 specific attributes of the product. So, the expression finally chosen was "Catalonia Sacra", as has been repeated throughout the text. Here, the form Catalonia comes from the Latin (a language traditionally used by the Christian church in its rites) and not from the English, as might be thought considering it is the standard language of marketing. As for Sacra, this is an adjective that attempts to communicate the fact that what is on offer is not merely another historicist or artistic discourse on heritage, but rather one focusing on the spiritual, sacred aspects of this heritage, which are the reason for its existence.

The Catalonia Sacra brand is therefore intended to communicate the fact that, for the first time, organised routes covering the most important points of the Christian geography of 
Catalonia are being made available to visitors, narrated and interpreted by the Church itself. The positioning - understood as the image the target audience has of the product compared to the competition - that Catalonia Sacra mus pursue has to be a positioning by experiences. The logo chosen to accompany the Catalonia Sacra brand, a graphic based on a capital from Santa Maria de l'Estany representing the Visitation, follows this same philosophy. In itself it is an element from Romanesque sculpture (that is, an element evoking the art and the history implicit in this heritage), but beyond that it seeks to transmit a message of welcoming, serenity and spirituality.

\subsection{The routes}

Catalonia Sacra includes a structure integrating the heritage elements managed by the Church at three different territorial levels of interest from an organisational and conceptual point of view, giving rise to the conception of three types of route:

- centres route: including all the cathedrals in Catalonia.

- radial routes: offered within the context of each diocese (between 4 and 10).

- overall route: including the entire geography of the Catalan dioceses.

We will now look at what each of these routes consists of in a little more detail.

\subsubsection{Centres route: the Cathedrals of Cata- lonia}

There is no doubt that, in the collective imagination of Western societies and from the point of view of Romanticism, the Cathedral (often misunderstood as "big church") has become one of the paradigmatic historic/artistic monuments, justifying or at least helping to provide a positive valuation of a place as a tourist destination. The fact is that cathedrals are usually both monuments and containers of first-class works of art; they have also had a determining influence on the configuration of the European urban landscape. Catalonia is, in effect, a country with cathedrals which are, and which contain, extraordinary works of art receiving a remarkable number of visitors every year.

Following the configuration in 2004 of the new Catalan diocesan map, Catalonia has a total of 10 cathedrals in its territory, one for each bishopric.

Considering these centres, it is proposed to communicate the concept of a "cathedral" as the nucleus of a diocese, a reference point for all believers from the same bishopric and a place symbolising the residence of the bishop as head and father of the Catholic community. This fact is what, over the course of centuries, has generated extraordinary monumental and artistic sites, but it is also shown today in a living way in places that have not enjoyed such rich histories and abundant resources.

The centres route is not approached as a circuit that must be followed in a limited time, but,

Table 3: Existing cathedrals in the bishoprics of the Tarraconense Episcopal Conference. Source: Catalonia Sacra

\begin{tabular}{|l|l|l|}
\hline \multicolumn{2}{|c|}{ Existing cathedrals in the bishoprics of the Tarraconense Episcopal Conference } \\
\hline Bishopric & \multicolumn{1}{|c|}{ City/Town } & \multicolumn{1}{c|}{ Name } \\
\hline Urgell & Seu d'Urgell & Santa Maria d'Urgell Cathedral \\
\hline Solsona & Solsona & Santa Maria de Solsona Cathedral \\
\hline Vic & Vic & Sant Pere de Vic Cathedral \\
\hline Girona & Girona & Santa Maria Cathedral \\
\hline Terrassa & Terrassa & El Sant Esperit Basilica \\
\hline Barcelona & Barcelona & Santa Creu and Santa Eulàlia Cathedral \\
\hline Lleida & Lleida & $\begin{array}{l}\text { New Cathedral of Lleida, L'Assumpció de } \\
\text { Nostra Senyora Cathedral }\end{array}$ \\
\hline Tarragona & Tarragona & Santa Maria Cathedral \\
\hline Sant Feliu de Llobregat & Sant Feliu de Llobregat & Sant Llorenç Cathedral \\
\hline Tortosa & Tortosa & Santa Maria Cathedral \\
\hline
\end{tabular}


above all, as a way of offering all 10 cathedrals in the Catalan territory together. It is a product intended to:

a. Ensure a visit to a cathedral established as a tourist resource opens the door to visits to other cathedrals not conceptualised as such, or even as cathedrals in the common imagination, by visualising them as a set.

b. Providing all the Catalan cathedrals, without exception, with quality materials for interpreting and facilitating visits valuing the

\section{Illustration 1: L'Empordà route:} stone, sky and sea. Source: Catalonia Sacra

1. Sant Martí d'Empúries (church, archaeology and landscape)

2. Sant Miquel de Fluvià (Romanesque architecture and painting)

3. Sant Tomàs de Fluvià (Romanesque architecture and painting)

4. Canons' church of Vilabertran (architecture and spirituality)

5. Castelló d'Empúries (basilica and museum)

6. Cadaqués (church, altarpiece and landscape) monument and, in some cases, filling a gap in terms of materials of this kind.

\subsubsection{Radial routes: the character of the Catalan dioceses}

The radial routes are designed as tours offered within each diocese. Following criteria largely based on geographical coherence and communicational rationality, they highlight the most important heritage elements in each bishopric. Depending on its size and density of heritage, each diocese articulates several routes

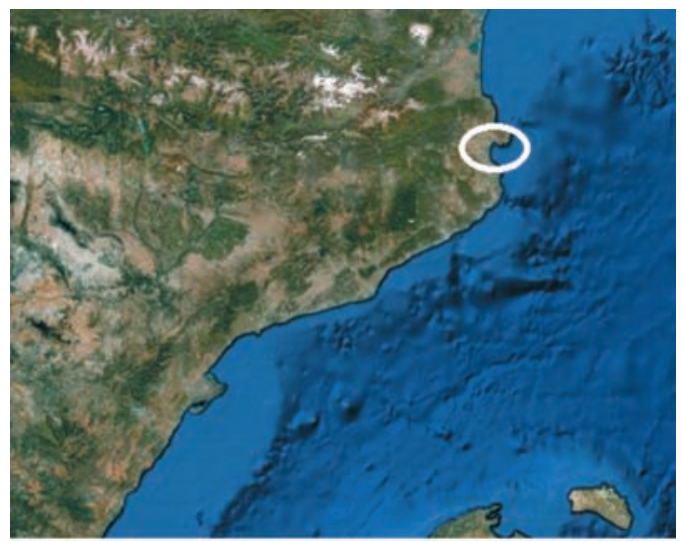

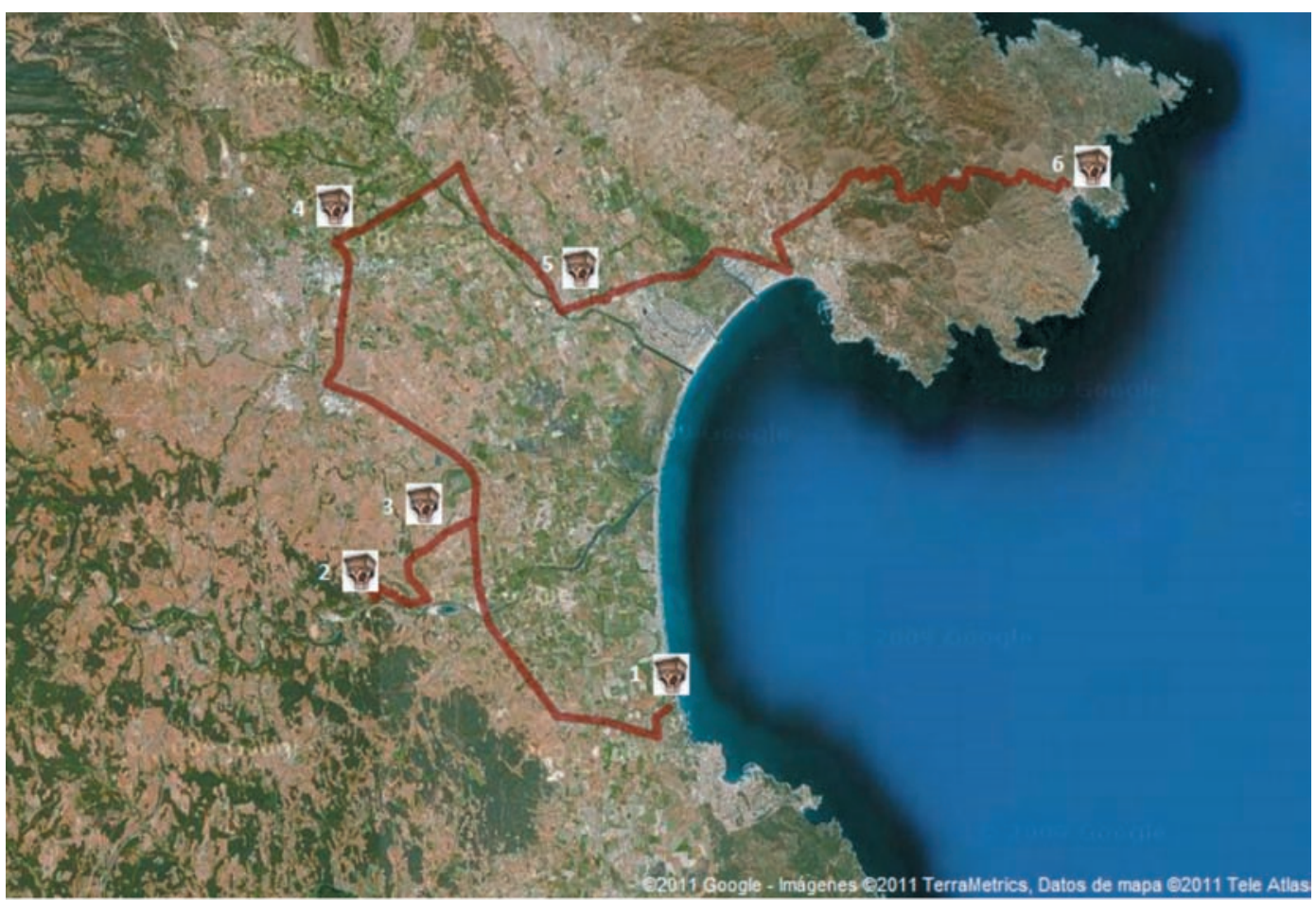


(between 3 and 8) covering its entire territory and including a selection of the most important heritage assets (as a rule between 20 and 60). A radial route starts from the diocesan capital or, depending on the case and the structure of the region, from a strategic population centre within the diocese, to create a tour which may or may not be circular, preferably undertaken by car and exploring a particular area of the diocese. Given general criteria of practicality and practicability, this area may be defined according to different characteristics: landscape, history, artistic sites, etc., and a title is suggested for each one, acting as a kind of sub-brand to define it. The estimated time for covering a route would be one or two days, as the range is intended for day-trippers or those on weekend breaks. By way of example, here is the radial route proposed for the Empordà area:

\subsubsection{Overall route: geography and identity of Christianity in Catalonia}

The idea of the overall route is to create a tour (or tours) which, by combining various elements of Church heritage in Catalan territory, should aspire to show the presence of religion, and specifically Christianity, in Catalonia. In this sense, an overall route is conceived as a way of structuring heritage elements - like the centres route - and, at the same time, as a collection of practicable tours - like the radial routes. It could be explored in stages, organised flexibly within a general concept, and has a dual aim:

a. to include various types of heritage linked to the church and represented by the most notable elements which are also the most appropriate ones for communicating and articulating the region (in this sense, the regional communications network and territorial interest take priority)

b. explaining the fundamental character of the Christian heritage (spaces, works of art, landscape and territory) in relation to the Christian faith, along with its relationship with the history and identity of the country.

In the overall route an attempt will be made to show the different aspects of the situation of Christianity in Catalonia over time as part of a story making it possible to move from more general issues (the anthropology of the holy, spirituality, the form and use of holy spaces, sacralisation of natural places, priesthood, mysticism, monasticism, religion and community, religion and power) to events in the Catalan context (history of the Church in Catalonia, establishment and presence of the monastic and conventual orders, organisation and expansion of the diocesan structure) to more specific issues relating to particular centres, places or buildings being visited.

This will be achieved by selecting the most important Church heritage elements in Catalonia, making it possible to exemplify and explain the principles of the programme satisfactorily. Many of these places, already established as tourism centres either independently or in the context of other routes, will form true heritage links, making it easy to see what the visitor facilities will be. This overall route, which will also have an identifier (own sub-brand), is still currently being configured.

\subsection{Communication of the brand and inter- pretation of heritage elements}

As a brand and a product, this range needs to be coherent - from the point of view of practicability (criteria of communication, accessibility, time needed) but also with a view to making it possible to communicate a series of additional realities linked to the same elements. These realities connect them with one another and with the region and therefore improve comprehension of this set of elements (regional or landscape coherence, historical and administrative criteria, etc.).

The first phase of creating the product includes the creation of the centres routes (tours of each cathedral) and a radial route for each diocese. Once this has been done and once the corporate identity (brand and logo) have been defined, it will be necessary to begin brand communication activities. The brand and the various products on offer will largely be structured through an official Catalonia Sacra website, where it will be possible to look up information about the suggested elements and routes as well as possible ways of covering them. The design of this website is currently being prepared, and it is hoped it will come into operation during the first half of this year.

As well as information about Catalonia Sacra, existing routes promoted by other regional bodies (county councils, municipal councils, etc.) and ways of combining the suggested routes will also be mentioned. This will allow tourists not only to discover the holy and spiritual Christian legacy but also to gain a deeper knowledge of the region they are visiting, based on various aspects of its identity. 
Clearly, once this portal comes into operation, an online marketing strategy must be implemented. Among other actions, this will include publishing a newsletter (which means having one or more databases of end customers and professionals in the sector), search engine positioning, using 2.0 tools (social networks, video and image websites, etc.) and, finally, managing digital identity (What are they saying about us on the net?) and online public relations (professional bloggers, press releases on electronic media, etc.) (Peñarroya 2010). Just as important as online public relations are personal public relations. For this reason, when the project comes into operation there will be presentations to members of the Tarraconense Episcopal Conference so that they know exactly what the Catalonia Sacra brand is and how their heritage is finally being promoted (following their indications). After this initial internal communication, actions will be carried out to familiarise tourism professionals from different areas with the product so that they know about it and in order to establish cooperative links with them.

Concerning the end customer, it is felt that signposting and interpretation tools for each of the elements comprising the routes are particularly important. Tours will therefore be offered with specialist guides. In addition, from the beginning, all cathedrals will be supplied with information leaflets regarding their Christian spiritual value (rather than their historical or artistic value). Later it is hoped that all heritage elements will be supplied with these materials. In the same way, the project website also needs to become an important point for information and heritage interpretation, so that visitors can prepare for their visits.

\section{Conclusion}

Besides the possibility of generating financial resources through the sale of specific products linked to the brand, notable benefits are obtained merely through Catalonia Sacra's action in publicising and promoting the heritage, most importantly the following:

a. Offering the public quality tours of the Church's cultural heritage.

b. Giving an overall view of the history of the Catalan Church.

c. Increasing visits to the different spaces and redistributing flows.

d. Alongside this, obtaining a platform for publicising the Church's cultural heritage. e. Obtaining an active, up-to-date website about the Church's cultural heritage.

f. Promoting this existing heritage which, except for some outstanding cases, is usually off the main tourist circuits, from a new perspective.

g. Contributing to increasing the social esteem of Christian heritage, which should lead to improved preservation of these elements.

In tourism terms, it is hoped that Catalonia Sacra will help to distribute tourist flows over the territory of Catalonia, particularly redirecting flows from the most saturated nodes (such as Barcelona Cathedral) to others which, despite their interest, are practically unknown even among Catalans (such as Sant Feliu de Llobregat Cathedral). In addition, these are routes mainly to be followed by car (rather than walking or cycle tourism routes), so their practicability does not depend on the weather and they are not subject to traditional tourist seasons. The very name of the brand, Catalonia Sacra, reveals a clear response to the growing demand for religious and spiritual tourism, not just in terms of tangible heritage elements but also by offering a reading or interpretation of interest to that type of visitor. At the same time, the discourse created is also interesting for the local population, who are very often unaware of this part of their history.

\section{References}

Aulet, S.

Competitivitat del turisme religiós en el marc contemporani. Els espais sagrats i el turisme. Unpublished $\mathrm{PhD}$ thesis, University of Girona, Girona. Accessed 5 May 2013, from http://www.tdx.cat/handle/10803/96379

Andriotis, K.

2009 "Sacred site experience. A Phenomenologial Studi". Annals of Tourism Research, 36(1): 64-84

Atles del Turisme a Catalunya

2009 Mapa nacional dels recursos turístics intangibles. Accessed 15 May 2013., from http:// www.gencat.cat/diue/doc/doc_36886208_1. pdf..

Chias, J.

2005 El Negocio de la felicidad: desarrollo y marketing turístico de países, regiones, ciudades y lugares. Madrid: Prentice Hall. 
Costa, N.

1992 "Il pellegrino e il turista: dalla contrapposizione alla contiguità del Ruolo". In Mazza C. (coord.), Turismo religioso, feste, culture istituzioni e vita cuotidiana (p. 69-82). Ravenna, Longo.

Flitterman-Lewis, S.

1990 To Desire Differently: Feminism and the French Cinema, Urbana and Chicago: University of Chicago Press.

Generalitat de Catalunya

2010116 Icones turístiques de Catalunya. Accessed 15 May 2013, from http://www. gencat.cat/diue/serveis/publicacions/turisme/ icones/116icones/arxius/index.html

Hakobyan, K.

2010 Conceptualización del turismo religioso y su aplicación en el proyecto Catalonia Sacra. unpublished master thesis, Girona University.

Hottel, R.

1999 "Including Ourselves: The Role of Female Spectators" in Agnès Varda's Le bonheur and L'une chante, l'autre pas', Cinema Journal, 38(2): 52-72.

Hughes, K., Bond, N., Ballantyne, R.

2013 "Designing and managing interpretive experiences at religious sites: Visitors' perceptions of Canterbury Cathedral". Tourism Management, 36: 210-220.

Kolb, B.M.

2006 Tourism Marketing for Cities and Towns. Amsterdam: Elsevier and Butterworth-Heinemann

Kotler, P.

2008 Principios de marketing. Madrid: Pearson Educación.

Norman, A.

2011 Spiritual tourism: travel and religious tourism in the Western Society. London: Continuum.

Olsen, D.H., Timothy, D.J. (ed.)

2006 Tourism, religion and spiritual journeys. London, New York: Routledge.

Parellada, J.E.

2009 El turismo religioso. Sus perfiles. Accessed 10 April 2013, from http://www.conferenciaepiscopal.es/pastoral/turismo/encuentro/2008/ JosepEnricParellada.pdf.

Peñarroya, M.

2010 Màrqueting electrònic per al turisme cultural. Bellcaire d'Empordà: Edicions Vitel la

Richards, G.

2007 Cultural tourism: global and local perspectives. New York: The Haworth Hospitality Press
Robles Salgado, L.J.

2001 Turismo religioso. Alternativa de apoyo a la preservación del patrimonio y desarrollo. Accessed 30 April 2013, from http://www. ub.es/geocrit/b3w-316.htm..

Rossello, M.

2009 Santuarios de Catalunya. Una geografía de lugares sagrados. Accessed 20 May 2013, from http://www.gencat.cat/diue/doc/ doc_35495018_1.pdf

Sharpley, R., Sundaram, P.

2005 "Tourism: a Sacred Journey? The Case of Ashram Tourism, India”. International Journal of Tourism Research, 7: 161-171.

Shinde, K.A.

2010 "Entrepreneurship and Indigenous Enterpreneurs in Religious Tourism in India". International Journal of Tourism Research, 12(5): 523-535.

Sureda Jubany, M.

2004 "La cathedral de Girona, matèria història. Historiografia a l'entorn de la seu". Annals de l'Institut d'Estudis Gironins, XLV, 69.109.

Turespaña

2010 Turismo religioso en España. Accessed 15 May 2013, from http://www.spain.info/es/ reportajes/turismo_religioso_en_espana.html

Turisme de Catalunya

2008 La imatge turística de Catalunya. Accessed 10 May, from http://www.gencat.cat/turistex nou/graf/Imatge_Catalunya08.pdf

Vidal Casellas, D.

2010 "Consideraçoes sobre a gestao dos itinerarios culturais". In Galí Espelt, N. (coord.) Itinerarios culturales: la experiencia del Camino de los Diamantes = Itinerarios Culturais: a experienca do Caminho dos Diamantes. Girona: Documenta Universitaria, Edicions a Petició.

World Tourism Organization.

2001 Tourism 2020 Vision. Global Forecast and Profiles of Market Segments. Madrid: World Tourism Organization

World Tourism Organization.

2007 The catholic church and tourism. Madrid: World Tourism Organization.

Recibido:

$17 / 04 / 2013$

Reenviado:

$03 / 05 / 2013$

Aceptado:

$01 / 07 / 2013$

Sometido a evaluación por pares anónimos 